\title{
The U.S.-Israeli Strategic Alliance: How the United States Is Contributing to a "Disappearing" Palestine
}

\author{
Denise De Garmo \\ Department of Political Science, Southern Illinois University, Edwardsville, IL, USA \\ Email: denise_degarmo@mac.com
}

Received 4 November 2015; accepted 3 January 2016; published 6 January 2016

Copyright (C) 2016 by authors and Scientific Research Publishing Inc.

This work is licensed under the Creative Commons Attribution International License (CC BY). http://creativecommons.org/licenses/by/4.0/

(c) (i) Open Access

\begin{abstract}
This paper examines the implications of the U.S.-Israeli strategic alliance on the proposed "two state solution". This alliance has its roots in common values and mutuality of national interests, interests that have produced intelligence sharing, technology transfer, and military assistance between the U.S. and Israel. These exchanges have led to extensive U.S. support of Israel's militarization in the Jordan Valley. It is also this strategic alliance that serves to support the continued annexation of the West Bank while diminishing future attempts at reaching a proposed "two state solution".
\end{abstract}

\section{Keywords}

Palestine, Israel, Jordan Valley, United States, Ballistic Missiles

\section{Introduction}

The United States and Israel have shared a strategic alliance since the creation of the state of Israel in 1948. This alliance is largely based on the provision of military weapons, training, and construction of military bases through the U.S. Department of Defense (USDOD) and the U.S. Army Corp of Engineers (USACE). As Israel expands its territorial control into the Jordan Valley through the construction of "closed military zones," "firing zones," and the like, one cannot help but wonder what assistance the USDOD and USACE has provided in these undertakings. This question became vital to one's understanding of the refusal of Israel to relinquish sectors of the Jordan Valley to the Palestinians under the auspices of the latest United States attempt at a brokered peace agreement in 2013. Can efforts by the Israelis to further militarize the Jordan Valley have something to do with this resistance? This question is at the core of this paper. 


\section{History of Area C: The Jordan Valley}

The concept of Area C, home to the Jordan Valley, was first outlined in the Interim Agreement on West Bank and Gaza Strip (1995) also known as the Oslo II agreement (Interim Agreement on West Bank and Gaza Strip, 1995). This declaration divided the territory of the West Bank into three distinct sectors: Area A, Area B, and Area C. The boundaries of Areas A and B were demarcated by drawing lines around Palestinian population centers at the time of Oslo I. However, this over-simplistic process resulted in boundaries that lacked territorial contiguity and led to issues regarding effective governance. The remaining territory not covered in Areas A and B became Area $\mathrm{C}$, which is territorially contiguous.

Area A encapsulates approximately eighteen percent of West Bank land (United Nations Office for the Coordination of Humanitarian Affairs: Occupied Palestinian Territory, 2014). It covers all Palestinian cities and most of the Palestinian population living in the West Bank. The Palestinian Authority provides civilian administration and security in this area. Area B covers approximately twenty-two percent of the West Bank and consists mainly of rural tracts of land (IBID). While the Palestinian Authority provides civilian supervision over Area B, security in this area has been handed over to the Civil Administration and Israeli Occupation Forces (IOF). The Civil Administration was established in 1981 by Israel to provide governance in the occupied territory of the West Bank. It is part of the Coordinator of Government Activities in the Territories COGAT) which is a unit in the Israeli Ministry of Defense.

The Palestinians originally conceived Area C as territory that would be used for future population growth and economic development though mineral extraction, use of water resources, development of agricultural and pastureland, and tourism. Article XXVII of the Oslo II Agreement supported these views by stipulating that Area C was to be returned incrementally to the Palestinian Authority by 1999 (Interim Agreement on West Bank and Gaza Strip, 1995). However, Article XXVII was never implemented. Area C continues to be under complete Israeli administrative and military control.

Area C is composed of approximately sixty percent of the West Bank. It consists of all Israeli settlements and associated jurisdictions, roads, “closed military areas”, “state land”, the "separation wall” and "nature reserves” and/or archeological sites (United Nations Office for the Coordination of Humanitarian Affairs: occupied Palestinian Territory, 2011). Less than five percent of the Palestinian population lives in this area (IBID). The Palestinian Authority provides only education and medical services to Palestinians living in Area C. However, the delivery of these services depends on the provision of appropriate infrastructures provided by the Israelis. Palestinian communities in Area $\mathrm{C}$ have limited access to water, sanitation, and electricity. There are high levels of food insecurity (World Food Programme, 2014). Palestinian construction and development in Area C are severely constrained.

As a new round of direct negotiations between Palestine and Israel transpired under the auspices of United States Secretary of State John Kerry in 2013, the territory known as the Jordan Valley came to the forefront of the negotiations. Israeli Prime Minister Binyamin Netanyahu pushed for the right of Israel to maintain Israeli Occupation Forces in the Jordan Valley specifically and Area C more generally for at least ten years. He also wanted Israel to continue to patrol West Bank's airspace with drones and early warning systems on a 24/7 basis (Frank, 2014).

\section{Israeli Militarization of the Jordan Valley}

Palestinian officials and non-governmental organizations have mostly focused on the issues of land expropriation and water exploitation by Israelis in the Jordan Valley. Evidence suggests that land and water are needed for extensive Israeli agricultural production and development (United Nations Office for the Coordination of Humanitarian Affairs: Occupied Palestinian Territory, 2011). Additionally, the presence of the IOF and associated military training exercises are seen as a way to expel remaining Palestinians and Bedouins from the Jordan Valley in order to extend total Israeli control over the land and its resources. However, significant military developments have been taking place in the Jordan Valley under the cover of "Firing Zones", "Closed Military Areas”, and IOF military bases. As Benyamin Netanyahu stated in 2001: "Nobody said what defined military zones were. Defined military zones are security zones; as far as I am concerned, the entire Jordan Valley is a defined military zone” (Roshandel \& Lean, 2011).

Since the Interim Agreement on West Bank and Gaza Strip (1995), ninety-five percent of the land in Area C, including most of the Jordan Valley has been deemed off-limits to Palestinians (United Nations Office for the 
Coordination of Humanitarian Affairs: Occupied Palestinian Territory, 2011). Fifty percent of this area is currently under the control of Israeli settlements (IBID). Forty-five percent is devoted to military use and "nature reserves" (IBID). "Closed military zones” have been used for military training exercises as well as a means of de facto land confiscation since 1970 (Badil, 2013: p. 66). The majority of these closed military zones are located in the southern Jordan Valley and the South Hebron Hills. The IOF and Civil Administration utilize Israeli Military Order 1651 to "designate large swathes of land as closed zones under auspices such as 'military training' justifying this 'necessary' requisition of land” (IBID). Under Article 318 of Military Order 1651, "A military commander is empowered to declare that an area or place is closed (IBID). Military Order 845 (1980) is used to exact penalties on unauthorized individuals who enter these zones without permission of the Military Commander (IBID). In addition to numerous closed military zones, several "nature reserves" are located within the Jordan Valley. The term "nature reserve" often designates additional land under use as a "closed military area".

Approximately twenty IOF military bases are known to dot the landscape of the Jordan Valley (IBID). No one knows for sure how many military bases actually exist in this area. Some military bases are situated along main roadways while others are hidden from view. Some of the bases have been dismantled and turned over to settlers. Others are held in reserve in case of emergencies. Still others serve as administration offices for the IOF. Israel is also responsible for coordinating military training missions in the Jordan Valley. In fact, military training can occur anywhere in this area regardless of proximity to Palestinian or Bedouin villages. While there have been many references to "Israeli forces" in the Jordan Valley, there have not been many details released about the composition of the Israeli forces, their equipment and the importance of their positioning in the Jordan Valley itself.

So why is the Jordan Valley of such vital importance to the state of Israel? Israel has consistently argued that due to "numerical, financial, and territorial disadvantages, its military planners must assume that their enemies' hostile intentions, to date, were thwarted by Israel's deterrent capacity” (Saar, 2001: pp. 64-65), a capacity predicated on occupying strategic terrain. The strategic territory referred to is the Jordan Valley or that area that encompasses the Jordan Rift Valley and the Judean-Samarian Plateau. Israel argues the Jordan Valley serves as a buffer zone that protects Israel's densely populated areas located in and around Tel Aviv (IBID, p. 72) while defending its borders with Arab states (IBID, p. 68).

However, the Jordan Valley is important to Israel for another purpose-it has immense strategic military value. The highlands provide concealment of "certain weapons systems, many of them requiring line-of-sight emplacement” (IBID, p. 65). These weapon systems serve as Israel's first line of defense against attack from the east. In addition to observation and control points, antenna arrays associated with Israel's early warning systems are located on numerous hilltops in the Jordan Valley. The highlands are particularly important to the placement of early warning systems because of the laws governing the transmission of electromagnetic radiation. Because the latter travel in straight paths, almost all sensors and antennas, the primary elements of many of today's sophisticated weapons, communications gear and control systems must be deployed in line-if-sight locations. The optimal places in Israel that furnish platforms for the arrays of antennas and sensors that have become the eyes and ears of modern armies, are located here (IBID, pp. 68-69).

These arrays are critical to the launching mechanisms associated with surface-to-air missiles, anti-ballistic missiles, and mid-range inter-continental ballistic missiles that are capable of carrying nuclear warheads such as the Jericho 2 and 3. The topography of the highlands also shields much of Israel from radar surveillance (IBID, p. 72). It makes sense for Israel to store artillery pieces, rocket launchers, ammunition, and support equipment in the Jordan Valley as well as further develop its military capabilities in the area.

\section{Enter the United States}

The late Republican Senator Jesse Helms used to call Israel “America's aircraft carrier in the Middle East,” when explaining why the US viewed Israel as such a strategic ally, saying that "the military foothold in the region offered by the Jewish State alone justified the military aid that the US grants Israel every year” (Arutz7 News, 2004).

The history of U.S. military aid to Israel certainly supports Helms' statement. The strategic alliance with Israel can be traced back to the origin of the state of Israel in 1948. During the Cold War, the U.S.S.R. and United States used the Middle East to balance their power against one another, Israel being of immense importance to helping the United States balance against the Soviet Union. This relationship was strengthened by the 1962 Kennedy Doctrine, which promoted the idea that it "was easier to live with an Israel that was getting the resources it needed 
to defend itself. Then Israel would not have to commit wild or unacceptable acts” (Riviv \& Melman, 1994: pp. 94-95). It was the intention of President Kennedy to provide Israel with defensive-use-only weapons. However the Johnson administration moved to ensure Israel's military superiority by selling it offensive weaponry such as 210M-48 Patton tanks, A-4 Skyhawk attack aircraft, and F-4 Phantoms thus establishing the maintenance of Israel's military edge as a strategic interest of the United States (Holt, 2014: p. 112).

The strategic alliance between Israel and United States became embedded within the North Atlantic Treaty Organization in 1987. A Memorandum of Understanding was signed by the United States and Israel. This memorandum acknowledged Israel as a non-North Atlantic Treaty Organization (NATO) ally while conferring it the same rights as full NATO allies (Chossudovsky, 2013). As Avigdor Lieberman, the Israeli Minister for Strategic Affairs stated "Israel's diplomatic and security goal... must be clear: joining NATO and entering the European Union" (Chossudovsky, 2013). Israel lost no time in taking advantage of its new status. Israel immediately began participating in the "Mediterranean Dialogue" and conducting joint military training exercises with NATO member countries (Chossudovsky, 2013). Israel also signed a joint security agreement with NATO in 2001 in response to the 9/11terrorist attacks against the United States.

Since the Wye River Memorandum (1998) the provision of services to Israel by the USArmy Corp of Engineers (USACE) has significantly increased (Mader, 2014). The USACE supports "the Israeli Air Force, Israeli Navy and the Israeli Occupation Forces through such projects as the design and construction of hangars, ports, maintenance facilities, and military training and infrastructure" (USACE Europe District, 2015) through the "U.S. Foreign Military Sales" program. However, in the aftermath of the 9/11 attacks against the United States, Israel became much more important as a strategic and intelligence ally to the United States especially since the US launched an invasion of Afghanistan and Iraq specifically, and the "War on Terror" more generally.

Not only did Israeli construction programs take center stage, so too did programs related to the improvement of intermediate range ballistic missile (IRBM) technology and ballistic missile defense. To date, the Israeli Ministry of Defense has become one of the largest customers of the USACE (IIBID). As a result the large number of programs growing out of this relationship, three USACE offices has been established in Israel. Here are some examples of the training and missile related work conducted in Israel under the auspices of the USACE.

In June 2007, the U.S. Army Corp of Engineers constructed a simulated urban training combat facility in the southern Negev desert (Israeli Defense Forces, 2011). IOF training at this facility often occurs alongside U.S. Marines. As Brigadier General Uzi Moskovich, commander of the Israeli National Ground Training Center commented: "This is something developed by us in cooperation with the U.S. Army; we intend for it to become a valuable center of knowledge that will also benefit our American allies and other friends (IBID)". In August that same year, Israel received \$3 billion in military aid from President George W. Bush's administration that would span a ten-year cycle (Israel Ministry of Foreign Affairs, 2007).

In 2008, the USACE constructed the "Army Navy/Transportable Radar Surveillance" base also in the Negev desert (Vick \& Klein, 2012). Unlike other military facilities constructed for Israel, this one is strictly under U.S. command. At any one time, one hundred U.S. soldiers are stationed at this facility (IBID). The phased array radar is designed to track ballistic missiles through space and provide ground-based missiles with the targeting data needed to intercept them (IBID).

In 2012, U.S. Army Corp of Engineers contractors began the construction of a "secret" air force base called "site 911" outside Tel Aviv at a cost of \$100 million (Congressional Record, 1999). The USACE also supervised a \$20 million project to build maintenance shops, hangars and headquarters to support Israel’s large Eitan unmanned aerial vehicle (IBID). In addition to military bases in "southern Israel, including the Nevatim air base, the U.S. has built command centers, intelligence facilities, simulators, and underground hangars to protect Israel's jet aircraft” (Jane's, 2013). Another secret construction effort between the United States and Israel was documented in a commercial magazine called Engineering in Europe.

The trade industry publication described the US construction of 3 military bases in Israel, built to house and support 20,000 troops. According to the outlet, the Israeli Air Force eventually moved into one of the bases after the US Army Corps of Engineers constructed a 2.5 mile long runway, 100 buildings and more than 10 miles of roads around the area (IBID).

According to William M. Arkin, in addition to military infrastructure and weapons sales, the United States has constructed "secret" U.S. Army bases throughout Israel. According to Larkin one facility is located "at Ben Gurion Airport and another in Herzliya Pituah" (Arutz Sheva7, 2004). Arkin reveals the bases, called Sites 51, 53, 54, 55 and 56 don’t appear on any maps and their specific locations are classified and highly sensitive. It is at 
those sites that the United States has "prepositioned" vehicles, military equipment, even a 500-bed hospital, for US Marines, Special Forces, and Air Force fighter and bomber aircraft at least six sites in Israel, all part of what is antiseptically described as "US-Israel strategic cooperation" (IBID).

Arkin states the equipment at these sites is owned by the United States and is for the use of the U.S. military. However, the equipment could be transferred to Israel in a time of crisis under the "Foreign Assistance Act" on a declaration of DEFCON 2, and under existing country memoranda of agreement (IBID).

The United States and Israel also have an extensive history of joint military training exercises, especially in the area of ballistic and anti-ballistic missile training (Hunt, 2005). Some of the more notable joint missile training exercises include the biennial "Juniper Cobra" and "Austere Challenge". The "Juniper Cobra" exercises began in 2005 with the most recent exercise held in May 2014. These joint exercises support continued training in anti-ballistic missile interceptors (Arrow, Arrow II and Arrow III), Patriot missile defense, Iron Dome and David's Sling system (IBID).

"Austere Challenge” (October 2012) involved training in missile defense involving the United States, Germany, Israel and Great Britain (IBID). In conversations with American soldiers headed to Israel for joint military exercises, the author confirmed that training alongside Israeli Occupation Forces is not limited to Israel proper. They report having attended military exercises in the Jordan Valley/Area C as well. Bedouins living in "closed military zones" have independently confirmed these assertions to the author during interviews.

More recently it was revealed in February 2014 that the U.S. established a secret National Security Agency satellite facility on Mount Scopus in occupied East Jerusalem (Silverstein, 2014). The facility is located within an Israeli SIGINT base called Ofrit, which intercepts telecommunications throughout the West Bank (IBID). As Silverstein observes: "I've never heard of a U.S. intelligence facility housed within an Israeli military base. This brings home even more strongly how little separation there now is between Israeli and American intelligence operations, as well as the willingness of the U.S. to establish bases in occupied territory (IBID)".

The military relationship between the United States and Israel is "the most extensive bilateral relationship in the world” (Holt, 2014: p. 112). Since 1949, the United States has invested over $\$ 70$ billion in Israel's military sector, forty percent of which has been provided in the last decade (Sharp, 2013: p. 6). Joint U.S. and Israeli research and development initiatives have yielded cutting edge weapons systems, including multi-tiered missile and rocket defense systems. Israel has also taken advantage of the U.S. Department of Defense's Excess Defense Articles (EDA) Program. Through this program more than \$330 million in materials has been transferred since 2001 to the Israeli Occupation Forces (IBID).The "emergency U.S. stockpile of weapons or the War Reserves Stock Allies-Israel (WRSA-I) is the physical storage of U.S. weaponry in Israel”. These materials can be released or sold to the Israeli Occupation Forces if authorized by the President in times of war (IBID). Additionally, research and development in the area of missile development between the United States and Israel has taken off since 2000. Israel has several manufactures of missiles and missile parts within US territory. These manufacturers include but not limited to: AccuBeat, TowerJazz, IMCO, and Plasan Sasa (End the Occupation, 2015a, Israeli Weapons Makers in the US). US missile manufacturers located in Israel include but are not limited to: Lockheed, Raytheon, and CMC-USA (End the Occupation, 2015b, US Weapons Makers in Israel). These US companies collaborate with Israel missile manufacturers: Elisra Group, Israel Aerospace Industries and Rafael Advance Defense Systems (IBID).

\section{Ballistic Missiles in Jordan Valley?}

Israel's security concerns have been exacerbated by ongoing missile proliferation in the region. In March 2003, "The Jerusalem Center for Public Affairs" predicted that missile threats to Israel would extend beyond Iraq (Rubin, 2003). Currently Iran, Lebanon, Syria, Saudi Arabia, and Libya all pose missile threats to Israel (Rubin, 2003). In response to the growing interdependence of security needs between the United States and Israel, the United States adopted legislation H.R. 7177 The Naval Transport Act (2008) that secures Israel's "qualitative military edge (QME)” (Shapiro, 2011). The legislation provides for "Israel's ability to counter and defeat credible military threats from any individual state, coalition of states, or non-state actor, while sustaining minimal damages or casualties" (IBID). The tool that is used by the United States to ensure Israel's qualitative military edge is security assistance. For some three decades,

Israel has been the leading beneficiary of U.S. security assistance through the Foreign Military Financing program, or FMF. Currently, Israel receives $\$ 3$ billion per year in U.S. funding for training and equipment under 
FMF. To put this in perspective, the total FMF account is about $\$ 5.5$ billion annually and is distributed among some 70 countries. So it is a testament to our special security relationship that each year Israel accounts for 60 percent of U.S. security assistance funding distributed through FMF (IBID).

H.R. 4310 National Defense Authorization Act for Fiscal Year (2013) was signed into law by the United States on January 1, 2013. This legislation "urges the Department of Defense and the Department of State to explore with their Israeli counterparts and alert Congress of any requirements the Israeli Occupation Force may have for additional Iron Dome batteries, interceptors, or other equipment” (Sharpe, 2013).

Growing threats to Israel combined with the need for strategic advantage in the region by the U.S. can only mean one thing-growing militarization of Israel and the occupied Palestinian territories. While militarization of the Jordan Valley does serve the purpose of expropriating land from Palestinians, militarization serves a more important function. The strategic military value, discussed elsewhere in this paper, provides Israel with a military edge against its Arab neighbors and therefore, is particularly attractive to ballistic missile placement. To explore this possibility, satellite images were obtained in December 2014 by the author from Google Earth for nine specific sites located in the southeastern part of the Jordan Valley. These satellite images cover the time span of 1999-2012. One such site (SITE 1) is included here because of the military implications for Israel, the United States and the region.

Site 1 is located at Latitude $31^{\circ} 31^{\prime} 50.57^{\prime \prime} \mathrm{N}$ and Longitude $35^{\circ} 16^{\prime} 42.04 " \mathrm{E}$. Initial construction of this military site began in 2001 according to the satellite imagery. Roads and building foundations can be readily seen. Imagery from 2003 reveals little headway in construction associated with this site. However, in 2007 satellite imagery reveals a nearly complete military base with associated ballistic missile defense silos and command center. The construction of this site is once again reflective of work conducted by USACE in Israel. As mentioned elsewhere in this paper, the USACE has been responsible for the construction of Israeli military bases and associated nuclear weapons facilities since the Wye Agreement in 1998. From 2008 on this particular site has fallen victim to censorship associated with national security concerns.

\section{International Law?}

Under international law, Israel is seen as an "occupier" of the Palestinian territory. Occupation is the "effective provisional control of a certain power over a territory which is not under the formal sovereignty of that entity, without the volition of the actual sovereign” (Roberts, 1990: p. 47). Articles 42 - 561907 Hague Regulations and Section GC IV, articles 27 - 34 and 47 - 78 of the Fourth Geneva Convention, in addition to the provisions of Additional Protocol I and customary international humanitarian law spell out the duties and responsibilities of an occupying power. The main rules of the law applicable in case of Israeli occupation state:

- The occupant does not acquire sovereignty over the territory;

- Occupation is only a temporary situation, and the rights of the occupant are limited to the extent of that period;

- The occupying power must respect the laws in force in the occupied territory, unless they constitute a threat to its security or an obstacle to the application of the international law of occupation;

- The occupying power must take measures to restore and ensure, as far as possible, public order and safety;

- To the fullest extent of the means available to it, the occupying power must ensure sufficient hygiene and public health standards, as well as the provision of food and medical care to the population under occupation;

- The population in occupied territory cannot be forced to enlist in the occupier's armed forces;

- Collective or individual forcible transfers of population from and within the occupied territory are prohibited;

- Transfers of the civilian population of the occupying power into the occupied territory, regardless whether forcible or voluntary, are prohibited;

- Collective punishment is prohibited;

- The taking of hostages is prohibited;

- Reprisals against protected persons or their property are prohibited;

- The confiscation of private property by the occupant is prohibited;

- The destruction or seizure of enemy property is prohibited, unless absolutely required by military necessity during the conduct of hostilities; 


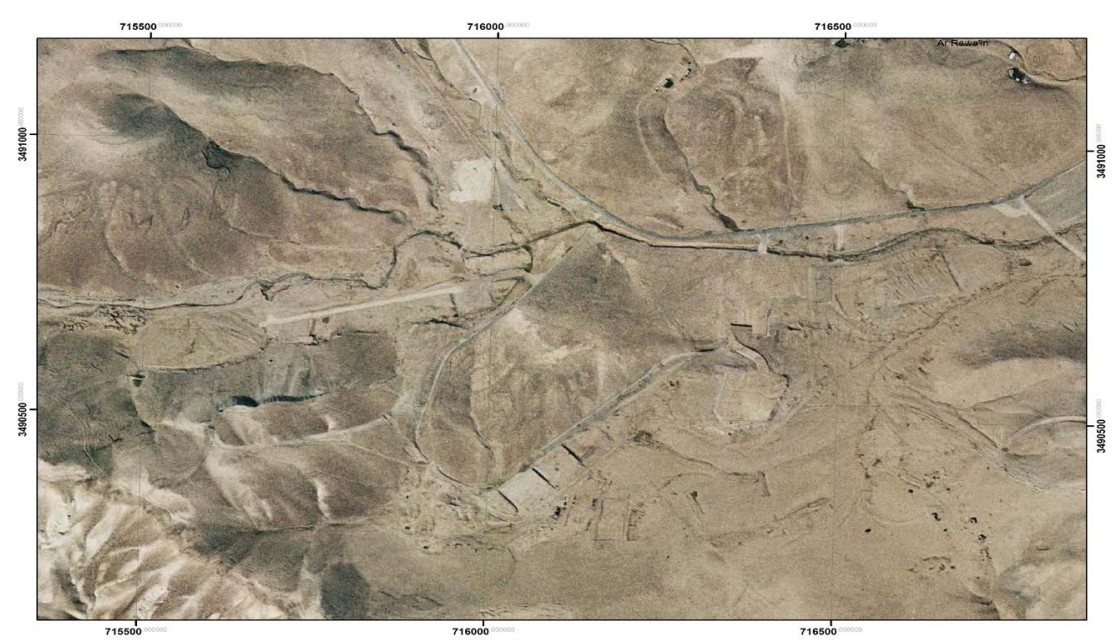

(a)

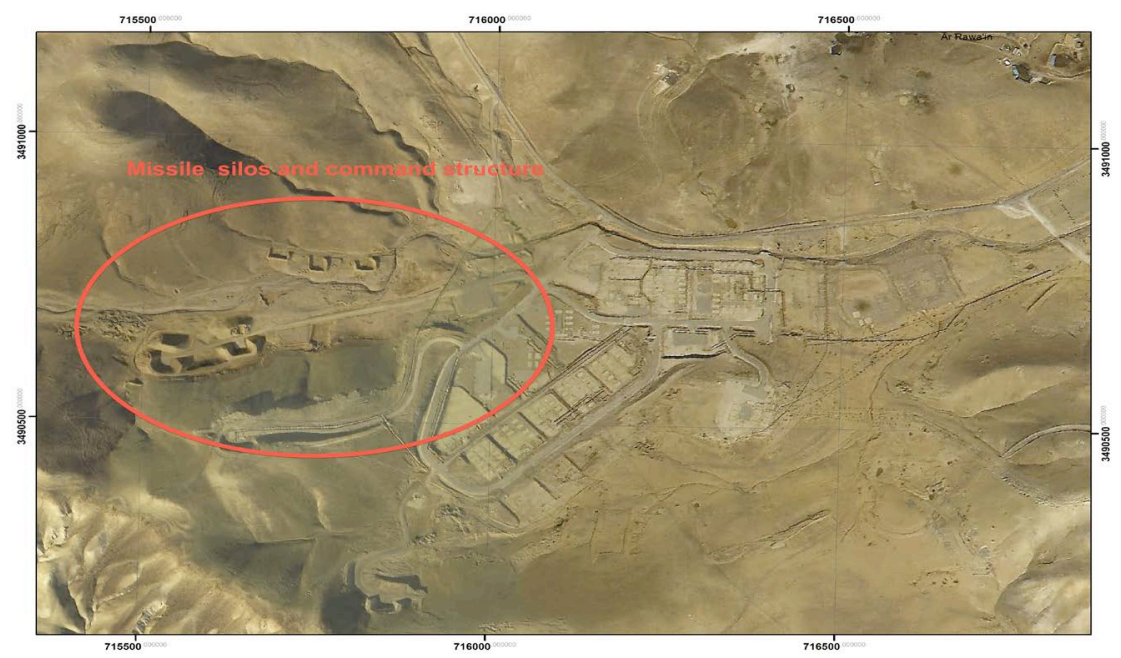

(b)

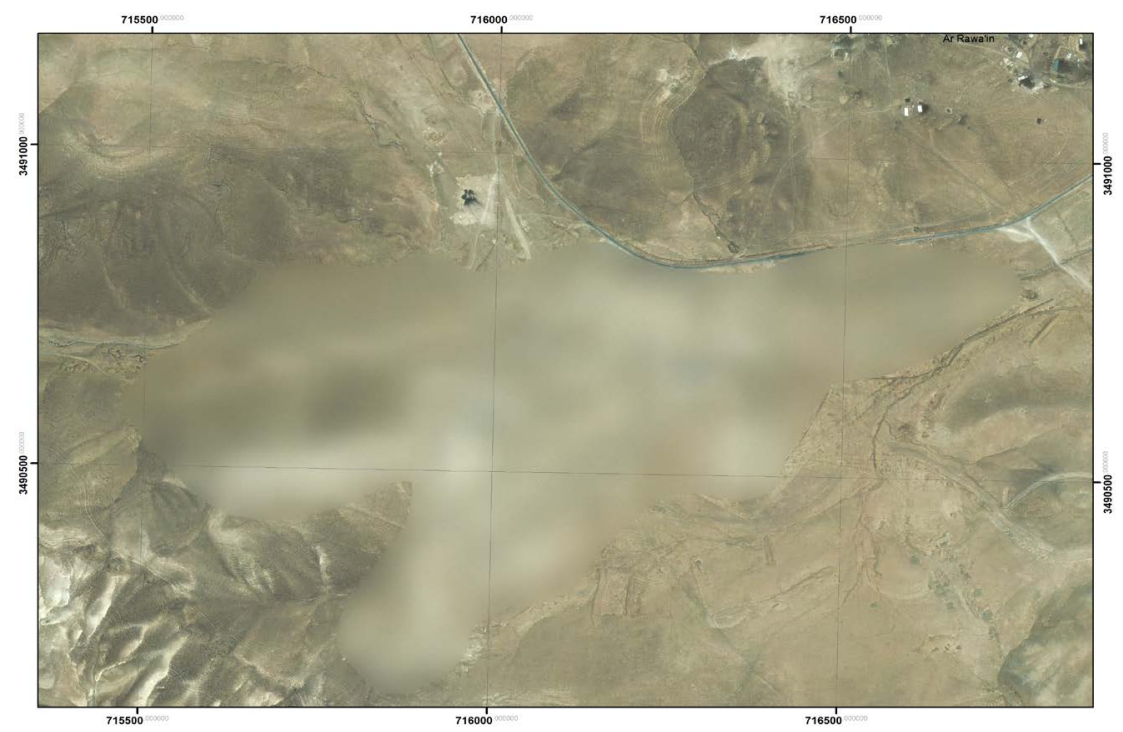

(c)

Size 1. (a) in 2001; (b) in 2007; (c) in 2012. 
- Cultural property must be respected;

- People accused of criminal offences shall be provided with proceedings respecting internationally recognized judicial guarantees (for example, they must be informed of the reason for their arrest, charged with a specific offence and given a fair trial as quickly as possible);

- Personnel of the International Red Cross/Red Crescent Movement must be allowed to carry out their humanitarian activities. The ICRC, in particular, must be given access to all protected persons, wherever they are, whether or not they are deprived of their liberty (International Committee of the Red Cross, 2004).

Clearly, the forced population transfer of Palestinians and Bedouins from the Jordan Valley and the transformation of private land for military purposes, including the installation of ballistic missiles are contrary to international law (Dugard, 2007: p. 3). The United States is in violation of the international laws of occupation through the provision of USACE services to Israel in territory under occupation. However, both Israel and the United States consistently ignore international law when it is not in their interests. This is nothing new. However, "American adherence to the standards of international law started to deviate after 9/11. America started to violate the laws, which it had helped to establish. Benjamin Netanyahu has reinforced this kind of violation" (Gresh, 2012). With impunity from international law, Israel and the United States will not change their behavior in regard to the militarization of the Jordan Valley. Once neighboring Arab states become aware of the installation of ballistic missiles in the Jordan Valley, in addition to the fact that these missiles allow Israel to acquire offense and defense superiority, one can only conclude that a new security dilemma will emerge in the region, a security dilemma involving the unfettered proliferation of missiles.

\section{Conclusion}

\section{As Jo Jakobson writes:}

Israel does not trust anyone. They are skeptical about other states' intentions, which are in large part one obvious legacy of the Second World War and its immediate aftermath. Of course, it is a given that Israel is skeptical toward its Arab neighbors (with whom they have fought many wars), and toward the Palestinians, and that its security strategies and its foreign (and domestic) policies reflect just this fact... Washington's support for Israel is fairly steadfast, that much is true (Jakobsen, 2012).

Survival and security constitute the totality of Israel's domestic and foreign policies. State survival has been a very real issue for Israel for over sixty years. The numerous wars with its "Arab neighbors have only bolstered and contributed to legitimizing Israel's self-declared status as a nation under permanent siege” (Jakobsen, 2012). In light of a widening range of threats to Israel from its neighbors and the growing interdependence of the strategic alliance between the United States and Israel, it is not surprising that the Jordan Valley has become the location of intensified military proliferation. The Israelis insist that the Jordan River must be the basis for a "first line of defense against threats that may someday emerge east of the river" (Eisenstadt \& Satloff, 2014). They insist on keeping early warning stations on the strategic hilltops of the West Bank and control of the electromagnetic spectrum in the Palestinian territories (Eisenstadt \& Satloff, 2014).

The defense policy of Israel has always been focused on maintaining defensible borders. The foreign policy of the United States is to use Israel as a forward "base" for its "War on Terror". From the perspective of the United States and Israel, it is important for these strategic allies to design a defense policy that takes into account the uncertainties they face with countries in the Middle East. Placing ballistic missiles that can carry nuclear warheads in the Jordan valley underscores the criticality for Israel to preserve the principle of defending itself by any means necessary. Given the strategic assets of the Jordan Valley, placement of ballistic missile defense silos, missile launchers and weapons storage facilities make sense to Israel and the United States. Israel has no intention of reaching any agreement with the Palestinians. Through settlement activity, land confiscations, water rationing, destruction of olive groves and other Palestinian agriculture, the establishment of large military no-go zones, travel and other restrictive measures encouraging emigration, Israel aims to reduce the Palestinian population to a point where they can be absorbed into Greater Israel, as a permanent minority. Gaza is left out of this calculation and will become a prison in perpetuity, caught between Israel and Egypt. The 1.5 million Palestinian refugees scattered across 58 refugee camps in 5 countries or jurisdictions have no place in the new Israel (United Nations Relief and Works Agency for Palestine Refugees in the Near East, 2015). The only thing absent from their calculation of security is the security dilemma. Israel has unleashed in the Middle East with the blessings of the United States. 


\section{References}

Arutz7 News (2004). Top Secret American Military Installations in Israel. http://www.jonathanpollard.org/2005/012805.htm Badil (2013). Israeli Land Grab and Forced Population Transfer of Palestinians.

Chossudovsky, M. (2013). Israel: A De Facto Member of NATO. http://www.globalresearch.ca/israel-a-de-facto-member-of-nato/5325890

Congressional Record (1999). V. 145, Pt. 17, p. 24099.

Dugard, J. (2007). Report of the Special Rapporteur on the Situation of Human Rights in the Palestinian Territories Occupied Since, A/HRC/4/17.

Eisenstadt, M., \& Satloff, R. (2014). Clarifying the Security Arrangements Debate: Israeli Forces in the Jordan Valley. http://www.washingtoninstitute.org/policy-analysis/view/clarifying-the-security-arrangements-debate-israeli-forces-in-thejordan-va

End the Occupation (2015a). Israeli Weapons Makers in the US. http://www.endtheoccupation.org/article.php?id=3651

End the Occupation (2015b). US Weapons Makers in Israel. http://endtheoccupation.org/article.php?id=3652

Frank, J. (2014). An Interview with Max Blumenthal-Inside Israel’s Apartheid State. http://www.opednews.com/articles/An-Interview-with-Max-Blum-by-Joshua-Frank-Apartheid_Goliath_Interviews_Israel140102-201.html

Gresh, A. (2012). French Writer Accuses US and Israel of Ignoring International Law. https://www.middleeastmonitor.com/news/europe/4347-french-writer-accuses-us-and-israel-of-ignoring-international-law

Holt, Blaine (2014). The Gold Standard: US-Israeli Military Relations. American Foreign Policy Interests, 36, 111-118.

Hunt, G. (2005). Air Defenders Train with Israeli Counterparts. http://www.globalsecurity.org/military/library/news/2005/11/mil-051102-arnews03.htm

Interim Agreement on West Bank and Gaza Strip Articles XI-XVII (1995). http://self.gutenberg.org/articles/Interim_Agreement_on_the_West_Bank_and_the_Gaza_Strip

International Committee of the Red Cross (2004). Occupation and International Humanitarian Law: Questions and Answers. http://www.icrc.org/eng/resources/documents/misc/634kfc.htm

Israel Ministry of Foreign Affairs (2007). Signing of Memorandum of Understanding between Israel and the United States.

Israeli Defense Forces (2011). Urban Warfare Training Center-Simulating the Modern Battlefield. http://www.idfblog.com/2011/10/26/urban-warfare-training-center-simulating-the-modern-battle-field/

Jakobsen, J. (2012). Israel-The Poster Child of Realism. http://www.popularsocialscience.com/2012/11/19/israel-the-poster-child-of-realism/

Jane’s (2013). U.S.-Built \$25-Million Base for Israel’s Arrow 3 ABM, Built to Counter Iran. http://www.globalresearch.ca/u-s-builds-25-million-military-base-for-israels-anti-missile-system-to-counter-iran/5337483

Mader, C. (2014). Washington’s Military Aid to Israel: Fake Peace Process, Real War Process. http://www.opendemocracy.net/arab-awakening/chase-madar/washington\%E2\%80\%99s-military-aid-to-israel-fake-peaceprocess-real-war-process

Order Regarding the Raising of Fines Stipulated in Security Legislation (Judea and Samaria) (No. 845), 1980.

Riviv, D. and Melman, Y. (1994). Friends in Deed: Inside the US-Israeli Alliance. New York: Hyperion.

Roberts, A. (1990). Prolonged Military Occupation: The Israeli-Occupied Territories since 1967. American Journal of International Law, 84, 44-103. http://dx.doi.org/10.2307/2203016

Roshandel, J. and Lean. N. (2011). Iran, Israel, and the United States: Regime Security vs. Political Legitimacy (p. 44). Westport, CT: Praeger.

Rubin, U. (2003). Beyond Iraq: Missile Proliferation in the Middle East. http://jcpa.org/article/beyond-iraq-missile-proliferation-in-the-middle-east/\#sthash.E7XQd307.dpuf

Saar, E. (2001). Israel: The West Bank and Modern Arms. In A. Stav (Ed.), Israel and the Palestinian State: Zero Sum Game? Shaarei Tikva: Ariel Center for Policy Research.

Shapiro, A. (2011). Ensuring Israel's Qualitative Military Edge, Remarks to The Washington Institute for Near East Policy. http://www.state.gov/t/pm/rls/rm/176684.htm

Sharpe, J. (2013). US Foreign Aid to Israel. Washington DC: Congressional Research Service.

Sharpe, J. (2014). US Foreign Aid to Israel. Washington DC: Congressional Research Service.

Silverstein, R. (2014). Secret NSA Satellite Facility Located at IDF Base in Occupied East Jerusalem. http://www.richardsilverstein.com/2014/02/10/secret-nsa-satellite-facility-located-in-jerusalem/ 
United Nations Office for the Coordination of Humanitarian Affairs: Occupied Palestinian Territory (2011). Humanitarian Factsheet on Area C of the West Bank. http://www.ochaopt.org/documents/ocha_opt_area_c_fact_sheet_july_2011.pdf

United Nations Office for the Coordination of Humanitarian Affairs: Occupied Palestinian Territory (2014). Humanitarian Factsheet on Area $\mathrm{C}$ of the West Bank.

http://www.ochaopt.org/documents/ocha_opt_area_c_factsheet_august_2014_english.pdf

United Nations Relief and Works Agency for Palestine Refugees in the Near East (2015). Palestine Refugees. http://www.unrwa.org/palestine-refugees

United States Army Corp. of Engineers (2015). Europe District. http://www.nau.usace.army.mil/

Vick, K. and Klein, A. (2012). How a US Radar Station in the Negev affects a Potential Israel-Iran Clash. http://content.time.com/time/world/article/0,8599,2115955,00.html

World Food Programme (2014). State of Palestine. http://www.wfp.org/countries/state-of-palestine 